\title{
BIOLOGICAL ASPECTS OF LYME DISEASE SPIROCHETES: UNIQUE BACTERIA OF THE BORRELIA BURGDORFERI SPECIES GROUP
}

\author{
Michal Krupka ${ }^{a *}$, Milan Raska ${ }^{\mathrm{a}}$, Jana Belakova ${ }^{\mathrm{a}}$, Milada Horynova ${ }^{\mathrm{a}}$, Radko Novotny ${ }^{\mathrm{b}}$, \\ Evzen Weigl ${ }^{\mathrm{a}}$
}

a Department of Immunology, Faculty of Medicine, Hnevotinska 3, Palacky University, 77515 Olomouc, Czech Republic

${ }^{b}$ Department of Microscopy Methods, Faculty of Medicine, Hnevotinska 3, Palacky University, 77515 Olomouc, Czech Republic

*e-mail:majkl.krupka@centrum.cz

Received: September 15, 2007; Accepted: November 28, 2007

Key words: Borrelia burgdorferi/Lyme disease/Spirochete

Background: Borrelia burgdorferi sensu lato is a group of at least twelve closely related species some of which are responsible for Lyme disease, the most frequent zoonosis in Europe and the USA. Many of the biological features of Borrelia are unique in prokaryotes and very interesting not only from the medical viewpoint but also from the view of molecular biology.

Methods: Relevant recent articles were searched using PubMed and Google search tools.

Results and Conclusion: This is a review of the biological, genetic and physiological features of the spirochete species group, Borrelia burgdorferi sensu lato. In spite of a lot of recent articles focused on B. burgdorferi sensu lato, many features of Borrelia biology remain obscure. It is one of the main reasons for persisting problems with prevention, diagnosis and therapy of Lyme disease. The aim of the review is to summarize ongoing current knowledge into a lucid and comprehensible form.

\section{INTRODUCTION}

Lyme disease is a chronic multi-system infectious disorder and the most frequent infectious arthropod-borne disease found both in Europe and the United States. The number of yearly reported cases continually increases in a number of geographical areas (Centers for Disease Control and Prevention Morbidity and Mortality Weekly Report, 2004). This may be due to the actual spread of the disease or alternatively, to improved diagnostic methods. Its significance is shown by the frequency of publications in medical journals that focus on infectious conditions. From this point of view, Lyme's disease has assumed a position just behind acquired immunodeficiency syndrome (AIDS) in recent decades ${ }^{1}$.

The disease is induced by spirochetes indicated totally as Borrelia burgdorferi sensu lato (Borrelia burgdorferi s. 1.). This group of microorganisms comprises at least twelve species (Tab. 1). Descriptions of new species and variants arises continously, so the number of species is probably not final.

The disease has a vector character. Most of the time, it is transmitted to humans by infected ticks of the genus Ixodes, but Borrelia has also been found in the midgut of the mosquitoes, Culex pipiens ${ }^{2,3}$ and Aedes vexans ${ }^{4}$. The presence of B. burgdorferi $\mathrm{s}$. s. was earlier described in the midgut of some species of mosquitoes and other blood sucking flies ${ }^{5}$. Hence transmission may be possible by other arthropods than ticks alone.
In about $70 \%$ of patients, the clinical picture of the disease starts as a pruriginous erythema at the site of the tick bite. Over time the erythema spreads out of the initial focus. The acute phase of the disease presents a picture of non-specific flu-like symptoms. Untreated, the disease develops toward arthritis and/or dermal, neurological or cardiac complications. Involvement of the nervous system may manifest as diffuse or focal neuropathy, painful radiculopathy, or less frequently, meningitis or encephalomyelitis. Neurological complications are frequently associated with infections caused by B. garinii and B. burgdorfer ${ }^{6}$. Among dermatological manifestations, typical are erythema, mentioned above, and acrodermatitis chronica atrophicans, which is caused mostly by $B$. afzelii ${ }^{7,8}$. Lymphocytoma and circumscribed scleroderma are less common. Ophthalmic disorders, most often intraocular inflammations, affected by Borrelia have been described as well ${ }^{9-11}$. A number of theories on the possible association between Borrelia infection and other poorly-understood syndromes have been published: sarcoidosis ${ }^{12,13}$, chronic fatigue syndrome ${ }^{14}$ and neurodegenerative disorders, e. g. Alzheimer's disease ${ }^{15,16}$.

Borreliosis is not only a problem in human medicine. Clinical forms have been found in a number of species of domestic animals, e.g. dogs, horses, cats and cattle. Interesting is the lack of clinical symptoms in forest animals. This may be the result of the long-term co-evolution of Borrelia and its natural hosts, such as deer, hares and various rodents ${ }^{17-19}$. 


\section{Basic microbiological characteristics}

The genus Borrelia, Swellengrebel 1907 is a member of the family Spirochetaceae which contain three genera - Borrelia, Leptospira and Treponema. Three genospecies forming the species group B. burgdorferi s. $s$. commonly cause human disease. In the USA only $B$. burgdorferi s. s. cause the disease, in contrast to Europe where $B$. affzeli and $B$. garinii are the most common. Some other species are irregularly pathogenic (Tab. 1). These differences in Borrelia geographic distribution have not been explained to date. Some species of Borrelia, not belonging to $B$. burgdorferi s. 1., are the cause of other human diseases, such as relapsing fever ${ }^{33}$.

Borreliae are unicellular spiral microorganisms without a rigid cellular wall 10-30 $\mu \mathrm{m}$ in length, 0,2-0,3 $\mu \mathrm{m}$ in diameter (Fig. 1). About 7-14 flagella at each end of the bacterium are responsible for Borrelia mobility. They are localized in periplasmatic space (Fig. 2). The rarity is the $B$. sinica with only 2-4 flagella, which may be the reason for its immobility ${ }^{30}$. The flagella consist mainly of two types of flagellin proteins - minor FlaA ( $38 \mathrm{kDa})$ and major FlaB (41 kDa) (ref. $\left.{ }^{34}\right)$. The shape of Borrelia is formed by flagellae that are twisted around the protoplasmatic cylinder but, in contrast to other bacteria, the Borrelia cell wall does not have an active role in shape determination. Targeted inactivation of the FlaB gene induces loss of motility and the "rod-like" form of these mutants ${ }^{35}$. Comprehensive reviews of the motility and cytoskeleton of spirochetes were published by Charon and Goldstein in 2002 (ref. ${ }^{36}$ ) and Wolgemuth, Charon, Goldstein and Goldstein in 2006 (ref. $^{37}$ ).

The composition of the cell envelope is similar to gram negative bacteria with some expressive differences, e. g. absence of lipopolysaccharide ${ }^{38}$ and an abundance of lipoproteins in the outer cell membrane ${ }^{39,40}$. As major lipid components of Borrelia membranes, identified are two phospholipids - phosphatidylcholine and phosphatidylglycerol and two atypical glycolipids - 1-O-palmi-
toyl-2-O-oleyl-3-O- $\alpha$-D-galactopyranosyl-sn-glycerol and Cholesteryl 6-O-palmitoyl- $\beta$-D-galactopyranoside. Both glycolipids are able to elicit the production of specific antibodies in mouse models. It was assumed, that these antibodies can cross-react with gangliosides and thus can be involved in the pathogenesis of neuroborreliosis. This aside, the synthesis of glycolipid based vaccines has been published $^{41-43}$.

Cultivation of Borrelia requires unique formulation of growing media. Several modifications of Barbour-StonnerKely's medium (BSK) allow the cultivation of spirochetes in fluid medium at high densities ${ }^{44}$. BSK is very complex medium containing mainly amino acids, cofactors, salts, $\mathrm{N}$-acetyl-D-glucosamine and a number of variable components such as bovine serum albumin, neopeptone, yeast extract and rabbit serum. Suppliers and a batch of a large number of the above ingredients can strongly affect growth rate, as well as the antigenic and morphologic characteristics of Borreliae ${ }^{45-47}$. Standardized medium, named BSK-H, is available commercially. Unique is the ability of Borrelia to grow in an iron ion-depleted environment, although iron level is limiting for a number of pathogenic bacteria. This feature of Borrelia is caused by elimination of most iron dependent matalloproteins and substituting $\mathrm{Mn}$ for $\mathrm{Fe}$ in the remaining metalloproteins ${ }^{48}$.

For the cultivation of Borrelia on solid medium, the BSK solidified by agarose is commonly used in a one or two layer modification ${ }^{49,50}$. The cultivation of Borrelia on solid medium enables the separation of individual colonies and thus selection of various genetic variants. Since some Borrelia strains do not grow in colonies on solid media, the limiting dilution method was developed for selection of Borrelia during cloning (D. S. SAMUELS, pers. comm.).

Another typical feature, which is not clearly understood until now is the formation of non-helical forms of Borrelia. Various cystic forms, blebs and L-forms have been repeatedly described during cultivation in medium
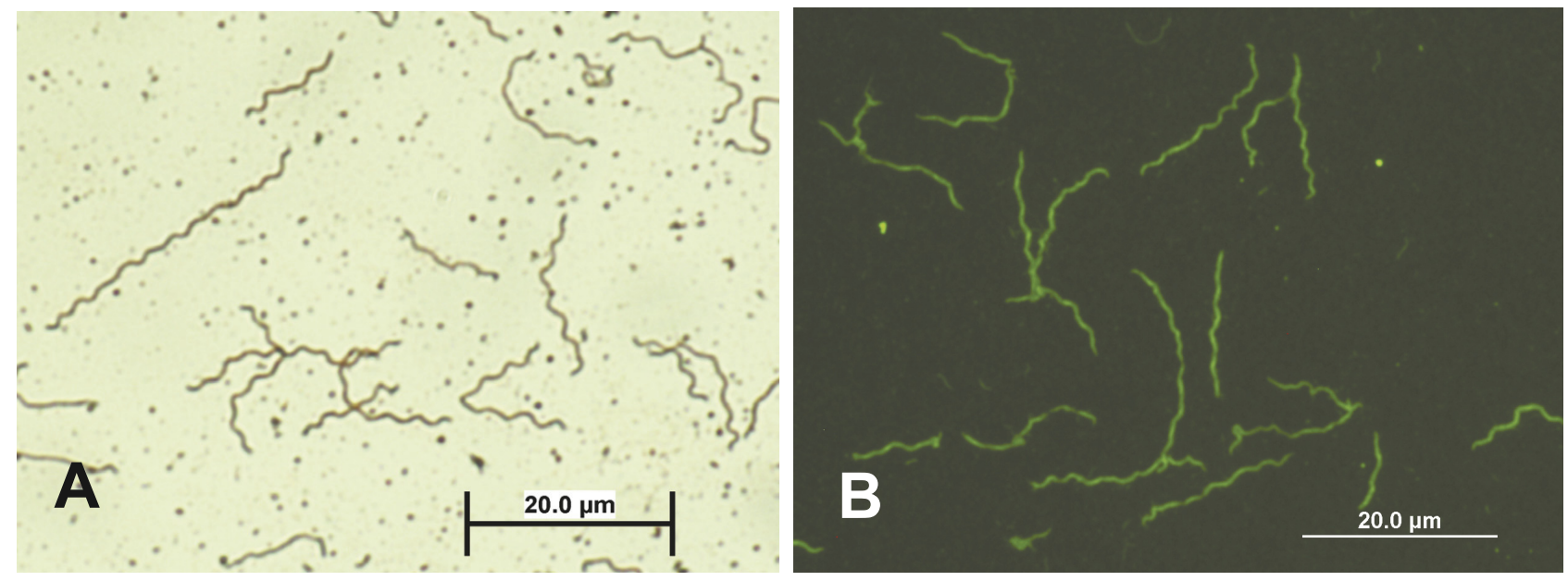

Fig. 1. Morphology of Borrelia burgdorferi:

A. Warthin-Starry silver nitrate staining.

B. Immunofluorescence - reaction with sera of needle-infected mouse. Magnification 1000x using immersion objective. 
Table 1. Species of B. burgdorferi complex.

\begin{tabular}{|c|c|c|c|}
\hline Species & Pathogenity for human & Geographical occurrence & Reference \\
\hline $\begin{array}{l}\text { B. burgdorferi sensu } \\
\text { stricto (s. s.) }\end{array}$ & Yes & USA and Western Europe & Johnson et al. ${ }^{20}$ \\
\hline B. garinii & Yes & Europe and part of Asia & Baranton et al. ${ }^{21}$ \\
\hline B. afzelii & Yes & Europe and part of Asia & Canica et al. ${ }^{22}$ \\
\hline B. japonica & not confirmed & Japan & Marconi et al. ${ }^{23}$ \\
\hline B. andersonii & not confirmed & North America & Marconi et al. ${ }^{23}$ \\
\hline B. tanukii & not confirmed & Japan & Fukunaga et al. ${ }^{24}$ \\
\hline B. turdi & not confirmed & Japan & Fukunaga et al. ${ }^{24}$ \\
\hline B. valaisiana & described rarely ${ }^{25}$ & Europe & Wang et al. ${ }^{26}$ \\
\hline B. lusitaniae & described rarely 27,28 & $\begin{array}{l}\text { Mediterranean and Middle } \\
\text { Europe }\end{array}$ & Le Fleche et al. ${ }^{29}$ \\
\hline B. sinica & not confirmed & China & Masuzawa et al. ${ }^{30}$ \\
\hline B. bissettii & not confirmed & USA & Postic et al. ${ }^{31}$ \\
\hline B. spielmanii & not confirmed & Western Europe & Richter et al. ${ }^{32}$ \\
\hline
\end{tabular}

Table 2. Replicons of B. burgdorferi s. s. strain B 31 MI ${ }^{39,63}$

\begin{tabular}{|c|c|c|c|c|}
\hline Replicon & Geometry & Size (bp) & $G+C(\%)$ & Coding (\%) \\
\hline Chromosome & Linear & 910725 & 28,6 & 93 \\
\hline cp9 & Circular & 9386 & 23,9 & 75 \\
\hline cp26 & Circular & 26498 & 26,5 & 88 \\
\hline cp32-1 & Circular & 30750 & 29,4 & 92 \\
\hline cp32-3 & Circular & 30223 & 28,9 & 92 \\
\hline cp32-4 & Circular & 30299 & 29,3 & 92 \\
\hline cp32-6 & Circular & 29838 & 29,3 & 92 \\
\hline cp32-7 & Circular & 30800 & 29,1 & 93 \\
\hline cp32-8 & Circular & 30885 & 29,1 & 92 \\
\hline cp32-9 & Circular & 30651 & 29,3 & 92 \\
\hline Ip5 & Linear & 5228 & 23,8 & 73 \\
\hline Ip17 & Linear & 16928 & 23,1 & 64 \\
\hline Ip21 & Linear & 18901 & 20,7 & 32 \\
\hline Ip25 & Linear & 24177 & 23,4 & 66 \\
\hline Ip28-1 & Linear & 28250 & 32,3 & 79 \\
\hline Ip28-2 & Linear & 29766 & 31,6 & 92 \\
\hline Ip28-3 & Linear & 28601 & 25 & 66 \\
\hline Ip28-4 & Linear & 27323 & 24,5 & 62 \\
\hline Ip36 & Linear & 36849 & 26,9 & 76 \\
\hline Ip38 & Linear & 38829 & 26,1 & 67 \\
\hline Ip54 & Linear & 53541 & 28,2 & 82 \\
\hline Ip56 & Linear & 52971 & 27,4 & 86 \\
\hline \multicolumn{2}{|c|}{ Plasmids total } & 610694 & 27,6 & 81 \\
\hline
\end{tabular}

a - Percent of plasmid occupied by genes and pseudogenes 

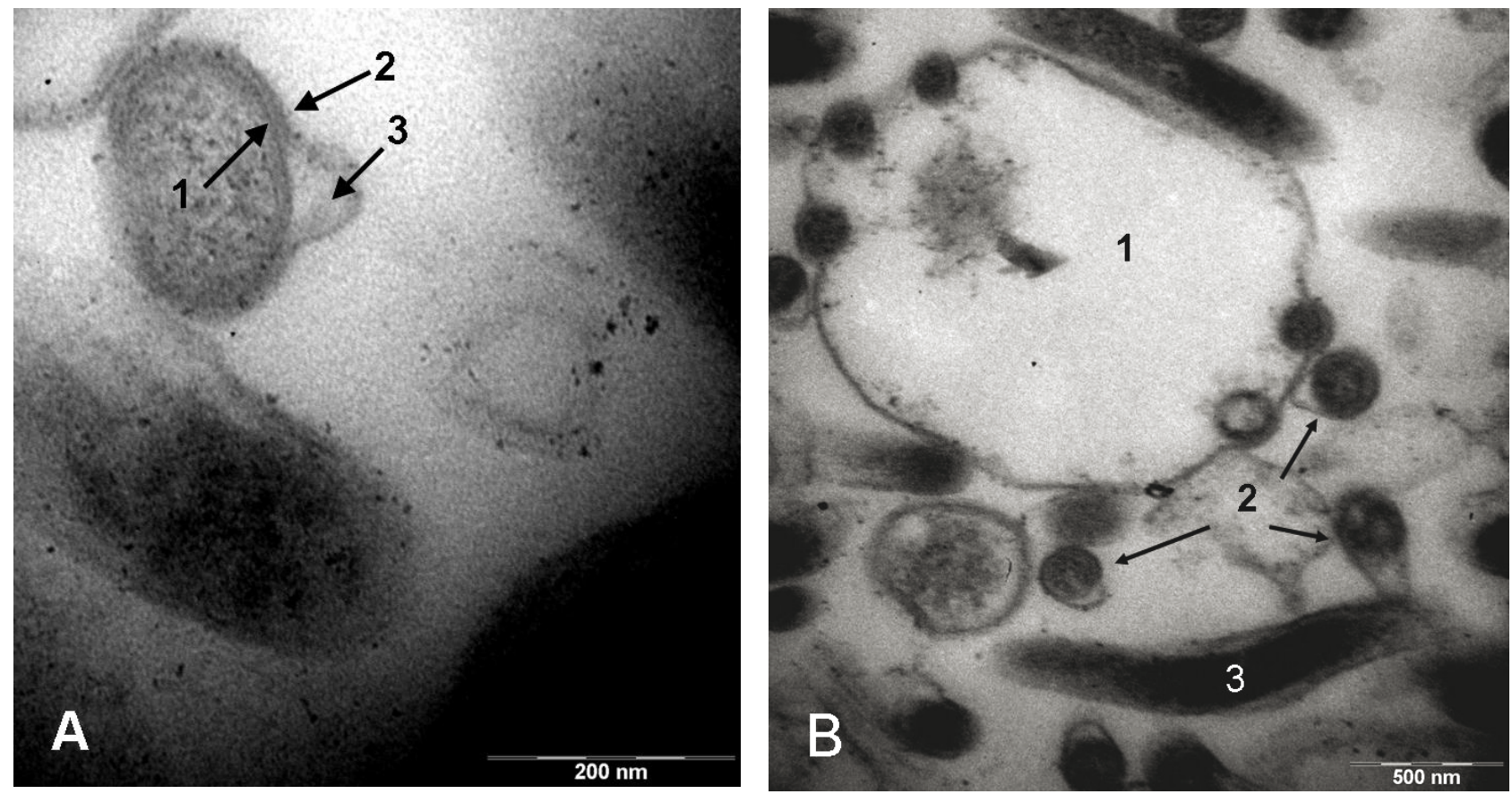

Fig. 2. Borrelia burgdorferi under Transmission Electron Microscope:

A. Transversal section, spiral form. 1 - inner membrane, 2 - outer membrane, 3 - periplasmatic space with flagella. B.

B. 1 - cystic form of Borrelia, 2 - transversal section, spiral form, 3 - longitudinal section, spiral form.

with non-optimal $\mathrm{pH}$, absence of serum, presence of antibiotics and in aged cultures, or generally under stress conditions. It seems that at least some of these transformations are reversible. A number of authors propose that these alternations are significant in the pathogenesis, immune evasion and/or antibiotic resistance of at least $B$. burgdorferi s. s. . $^{15,16,51-55}$.

Classic microbiological technologies are unsatisfactory for identifying Borrelia species and hence, molecular biology approaches (PCR, RFLP-PCR) prevail today. For taxonomy studies the DNA typing of $O s p A, O s p C, 16 \mathrm{~S}$ rRNA and 5S - 23S rRNA spacer are frequently used approaches.

\section{Genome structure}

The spirochetes of the genus Borrelia are unique bacteria. One characteristic feature of this microorganism is its unusual genome which consists of one linear chromosome with an approximate size of one mega base and several circular and linear plasmids ${ }^{39,56-63}$. The Borrelia chromosome is relatively small compared to other bacterial chromosomes whose size varies from 580 to $9300 \mathrm{kbp}^{64}$. In 1997 the genetic map of B. burgdorferi s. s. B31 was published $^{39}$, and later completed by Casjens et al. ${ }^{63}$.

The B. burgdorferi s. s. B31 MI chromosome was investigated by Casjens et al. ${ }^{63}$ and shown to contain 842 functional genes and only 1 pseudogene. Chromosomal genes code proteins necessary for replication, transcription, translation, energy metabolism, and transport of nutrients and ions. Neither chromosome nor plasmids contain genes for cellular biosynthetic reactions. This is the reason for the limited metabolic capacity of B. burgdorferi s. l., which lacks enzymes necessary for the biosynthesis of aminoacids, fatty acids, nucleotides and cofactors. This also explains the need for a complex medium containing all these components for the growth of the Lyme disease spirochetes. Of the other chromosomal genes, the most important are genes for DNA repair ( $m u t S, m u t L, u v r A$, $u v r B$, $u v r($ and $u v r D$ ), genes for homologous recombination (recA, recBCD, sbsC, sbsD, recG, ruvAB, recJ), genes for heat shock response (groES, groEL, grpE, dnaJ, hslU, $h s(V, d n a K, h t p G)$, and chemotactic factors-coding genes (cheR, cheW, cheA, cheY, cheB) (ref. ${ }^{39}$ ). The ends of the chromosome are formed by covalently closed hairpin telomeres. This feature is unusual for prokaryotes, but it has been found on DNA of double stranded DNA viruses and on some eukaryotic mitochondrial DNA molecules ${ }^{65}$.

In addition to the chromosome, 21 extrachromosomal replicons have been described in B31 strain: 9 circular plasmids (cp) and 12 linear plasmids (lp) (Tab. 2). This is the maximum number of plasmids described in bacteria to date ${ }^{63}$. Apart from this, two other plasmids (cp32-2 and $\mathrm{cp}$ 32-5) have been described in other subcultures of B31, which presumably means that the total number of plasmids in the original isolate B 31 was $23\left(\right.$ ref. $\left.^{66}\right)$. In other strains of B. burgdorferi s. s., the number of $\mathrm{cp} 32$ plasmids varies between 6 (strain N40) and 10 (strain Sh-2-82) (ref. $\left.{ }^{67}\right)$. Other unusual phenomena are the presence of a large number of pseudogenes on plasmids and low degree of identity between plasmid gene sequences 


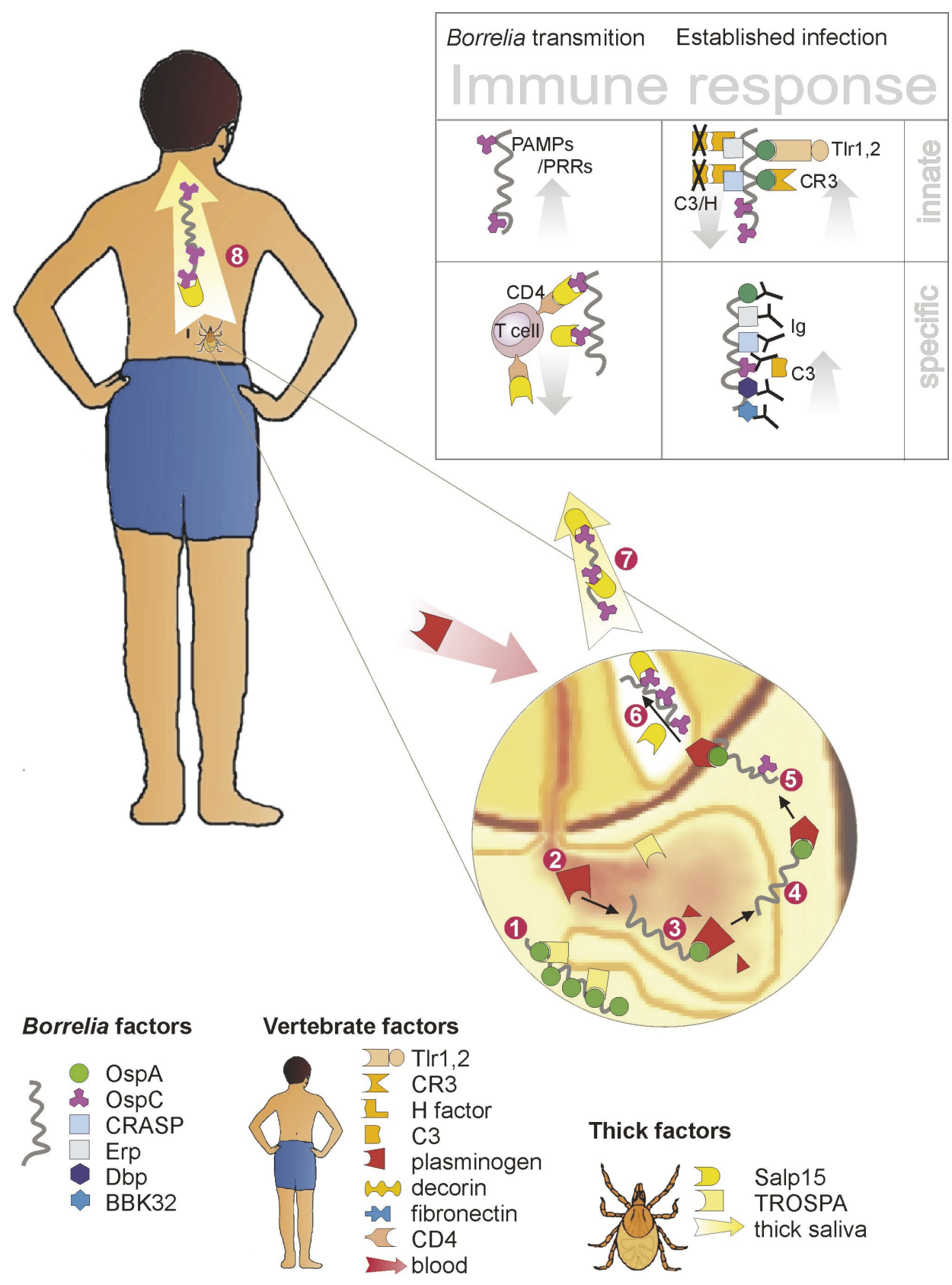

Fig. 3. Transmission of Borrelia burgdorferi from tick to human.

Borrelia binds tick gut epithelium via OspA-TROSPA interaction (1). Intake of human blood with plasminogen (2), which is subsequently bound on the OspA. Plasminogen after activation (3) helps Borrelia to pass through gut epithelium (4). Consequently Borrelia passes through haemocoel to salivary glands of tick (5). During this time, Borrelia changes its outer proteins profile and in the salivary glands binds immunosupresive Salp15 (6). "Armed" with this protein, Borrelia leaves tick (7) and enters to the human (8). Table in the upper right corner illustrates human immune reaction to Borrelia. Gray arrows indicate increasing or decreasing of immune response. Abbreviations are interpreted in the text.

and sequences of genes known from other organisms. Linear chromosomes end in hairpin telomeres similar to the chromosome telomeres ${ }^{68}$. This form, unusual for prokaryotes, was originally described in $\mathrm{N} 15$ prophage of $E$. coli - linear plasmid molecule with the above features ${ }^{69}$. Apart from Borrelia, linear plasmids have been described in Streptomyces, Rhodococcus fascians, Nocardia opaca, and in Thiobacillius versutus up to now ${ }^{70}$. Covalently closed hairpin telomeres have been found on DNA of double stranded DNA viruses and on some eukaryotic mitochondrial DNA molecules ${ }^{65}$.

Interesting is the high degree of genetic redundancy between some plasmids. Cp32 plasmids share sequence homology with each other and with plasmids lp56, lp54 and cp9. It seems very likely that $1 \mathrm{p} 54$ and $1 \mathrm{p} 56$ arose from integration of cp32 into linear progenitors. On 

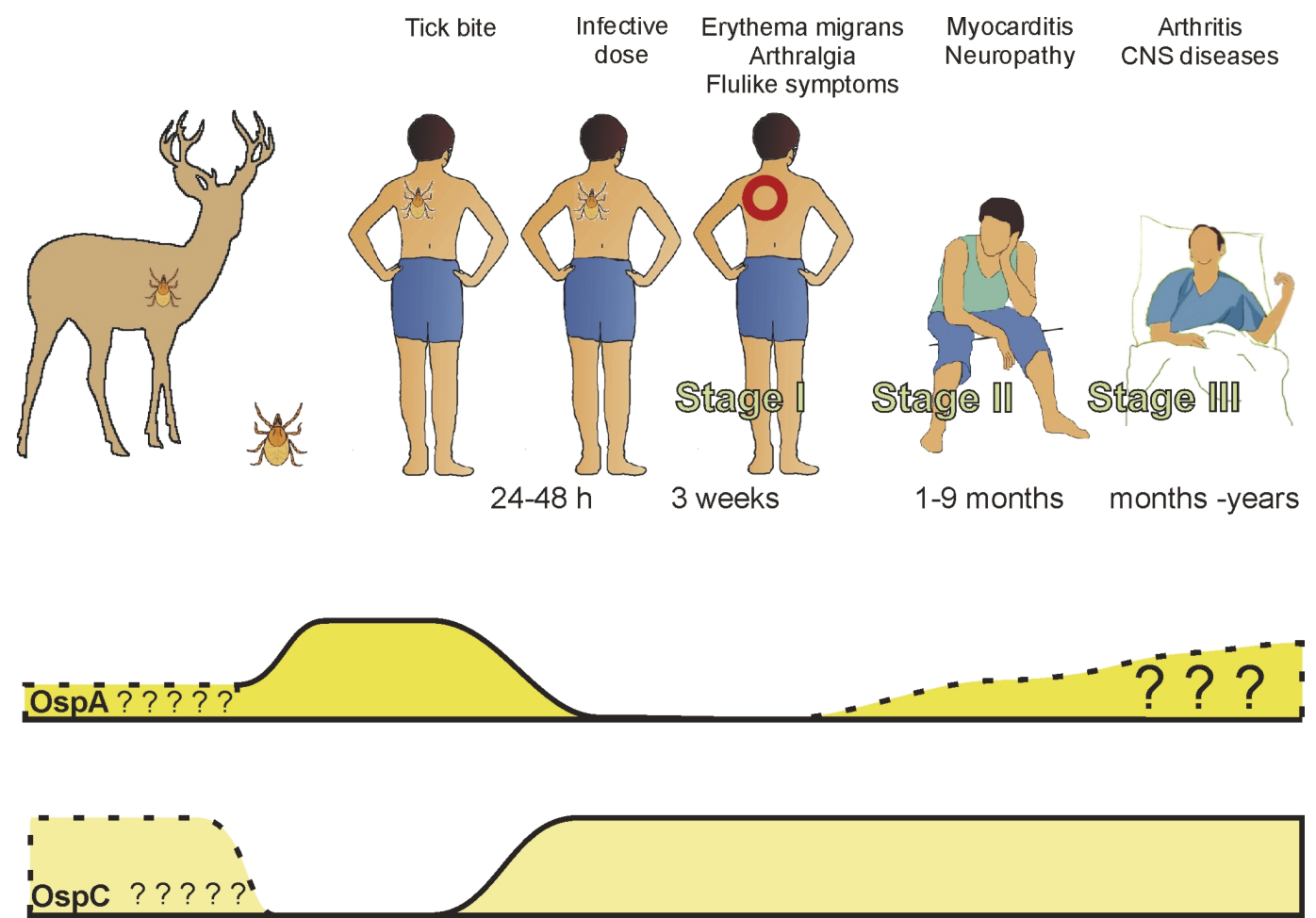

Fig. 4. Illustration of changing expression of OspA and $\mathrm{OspC}$ during Lyme disease transmission.

Expression of Osp's in the natural Borrelia's hosts is poorly known. Borrelia express OspA during tick infection, where OspA acts as a tick specific adhesive molecule. During transmission to human, expression of OspA decreases and expression of OspC increases. Some reports proved expression of OspA during later stages of human infection.
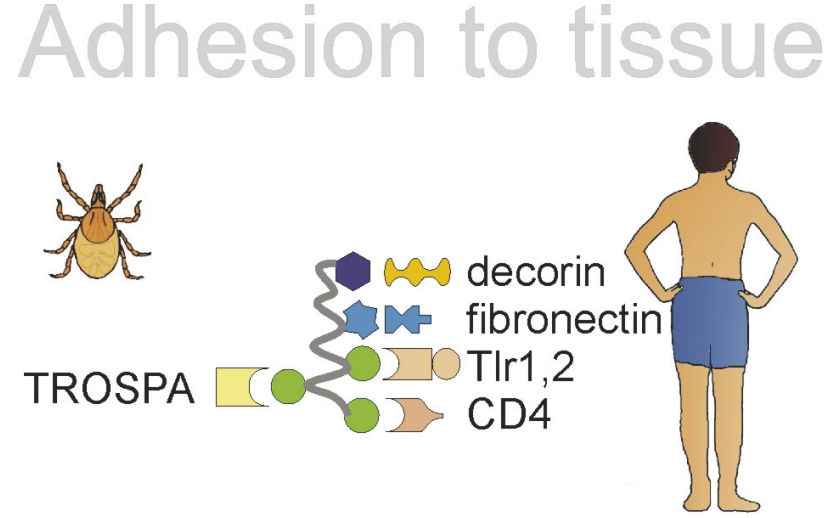

Fig. 5. Adhesion of Borrelia to tick and human tissues. Symbols are explained in Fig. 4.

the other hand, cp9 is probably a fragment of ancestral cp32. Another truncated member of cp32 family, cp 18 has been described in B. burgdorferi s. s. isolates N40 and 297 (ref. ${ }^{63,66,71,72}$ ). Other highly similar plasmids are lp5 and $1 p 21$ (ref. $\left.{ }^{63}\right)$.

Eggers et al. ${ }^{73,74}$ proved that cp32 plasmids contains prophage genome and they described bacteriophage mediated lateral gene transfer in B. burgdorferi s. s. This may be an important mechanism in Borrelia genome variability.
Glockner et al. ${ }^{75}$ compared genome of B. burgdorferi s. s. B31 with genomes of $B$. garinii strain PBi (isolated from cerebrospinal fluid) and $B$. afzelii strain BKo (skin isolate). Chromosomes of these three species have a high degree of similarity. Only three regions show greater differences - ori replicator and genes for membrane proteins bmp and lmp. Apart from this, plasmid content varies widely between these species, whereas $B$. garinii and $B$. afzelii are more similar to each other than to $B$. burgdorferi $S$. $S$. Plasmids of these three species were divided into 6 orthologous groups. Higher similarity was found in cp 26 analogs (B. garinii cp28, B. afzelii cp27) and in 1p54 analogs (B. garinii $1 \mathrm{p} 59$, B. afzelii $1 \mathrm{p} 60-1)$. Similarity in the other groups was significantly lower.

Some B. burgdorferi s. s. plasmids are not essential for in vitro Borrelia growth and thus can be easily lost when passaged out of its natural host. However, some of those genes are necessary during natural infection course and for Borrelia persistence in the host as demonstrated by Labandeira-Rey et al. ${ }^{76,77}$. They examined the infectivity of mutants lacking $1 \mathrm{p} 25$ and $1 \mathrm{p} 28-1$ in $\mathrm{C} 3 \mathrm{H}$ mice and demonstrated that the loss of infectivity in $1 \mathrm{p} 25^{-}$and elimination of $1 \mathrm{p} 28-1^{-}$mutants from tissues coincident with the onset of specific IgM immune response. In immune-deficient SCID mice, the $1 \mathrm{p} 28^{-}$mutants normally persist. This observation reveals the importance of some genes located on these plasmids: the gene for nicotinamidase (protein 
BBE22) substantial for bacteria metabolism, located on plasmid 25 and the gene for VlsE (Vmp-like sequence, expressed) important for immune evasion ${ }^{76-80}$ located on plasmid 28-1. Abberation in $v l s$ was associated with loss of infectivity of B. garinii $^{75}$. Purser and Norris ${ }^{81}$ tested 19 clonal isolates of $B$. burgdorferi s. $s$. of known plasmid pattern. They divided plasmids into three groups: the first group - plasmids required for infectivity (1p25, $1 \mathrm{p} 28-1)$, the second group - plasmids which were missing randomly in infective or non-infective isolates, thus not required for infectivity (cp9, cp32-3, lp21, 1p28-2, 1p28-4, 1p56), and a third group - plasmids presented in all 19 isolates (cp26, cp32-1, cp32-7, cp32-4, cp32-6, cp32-8, cp32-9, $1 \mathrm{p} 17, \operatorname{lp} 28-3,1 \mathrm{p} 36,1 \mathrm{p} 38$ and $\operatorname{lp} 54)$. A few years later, clinical B. Burgdorferi s. s. isolates lacking $1 \mathrm{p} 38,1 \mathrm{p} 56$, cp32-1, cp32-8, and segment of 28-1 were described ${ }^{82}$. In contrast to the majority of bacteria, some Borrelia plasmids carry genes essential for survival, as was demonstrated for plasmid cp26 (ref. ${ }^{83,84}$ ) coding at least three necessary proteins - GMP synthase (guaA), IMP dehydrogenase $(g u a B)$ and telomere resolvase ( $r e s T)$, the enzyme responsible for capping linear replicons with hairpin telomeres ${ }^{85}$. This is another speciality of the Borrelia genome as plasmids often carry genes that confer a selective advantage, but not genes necessary for the life cycle. Moreover, cp26 plasmid carries a gene coding for outer surface protein $\mathrm{C}$ $(\mathrm{OspC})$, which is necessary for early stage of vertebrate host infection but is not required during growth in the tick vector or during in vitro growth ${ }^{86-88}$.

Strother et al. ${ }^{89}$ tried to identify plasmids of $B$. burgdorferi required for tick infection. They demonstrated that plasmids $1 \mathrm{p} 5,1 \mathrm{p} 28-1$, and cp9 are not required for tick infection, whereas loss of $1 \mathrm{p} 25$ and $1 \mathrm{p} 28-4$ is associated with reduced tick infectivity. Moreover it was discovered that absence of $1 \mathrm{p} 28-1$ reduces transmission of Borrelia to tick salivary glands, the organ from which spirocheta is released to vertebrate host.

These data show that plasmids of B. burgdorferi s. l., especially linear ones, have some characteristics exceptional for common definition of "plasmid" - the redundant, mainly circular DNA molecule, conferring antibiotic resistance or other selective advantage and present in cells in variable number. In addition, linear plasmids have similar features to linear chromosome which supports the idea that at least some plasmids of B. burgdorferi s. 1. should be regarded as "minichromosomes"

\section{Outer membrane proteins and their significance in the pathogenesis and transmission of the disease}

Members of B. burgdorferi species group have a complex life cycle. All these species circulate between arthropod vector and vertebrate host. As mentioned above, the most frequent vectors are ticks of the genus Ixodes and vertebrate hosts originate from a broad range of avian and mammalian species.

During its life cycle Borrelia must adapt to two very different environments - tick and vertebrate organisms.
Borrelia must be able to adhere and survive in the tick gut, pass by gut epithelium to the haemolymph and transport through salivary glands to the host bloodstream, must avoid the immune reaction and disseminate to the target tissue. During Borrelia transition between Ixodes and vertebrate, a key role is played by several outer surface proteins. Their expression is regulated in separate phases of Borrelia infection ${ }^{91-94}$.

\section{Outer surface protein A}

The most known is antagonism between expression of outer surface protein A (OspA) and OspC in B. burgdorferi s. s. The OspA was the first described member of outer surface proteins - more precisely lipoproteins group ${ }^{95}$. OspA has molecular weight of $31 \mathrm{kDa}$. The gene for this protein is part of the bicistronic operon on plasmid 1p54 expressed together with the gene for another outer surface protein - OspB, with a molecular weight $34 \mathrm{kDa}^{96}$. These proteins are expressed in the midgut of tick, or in cultured Borrelia and are downregulated during transition to the vertebrate host $\mathrm{t}^{97}$. The main function of OspA consists in binding to glycoprotein TROSPA present in tick gut epithelium (tick receptor for OspA). The biological function of TROSPA glycoprotein in tick is unknown. Using quantitative RT-PCR, expression of TROSPA was shown to be significantly increased in Borrelia infected ticks. Another purported function of Borrelia OspA is the binding of plasminogen from the host blood during tick feeding. The phenomenon of plasminogen binding is described as the virulency factor in some other bacteria, e.g. Streptococcus, Salmonella, Haemophilus and Yersinia ${ }^{99}$. The presumed sense of OspA-induced plasminogen activation toward active plasmin is the misuse of its proteolytic activity for Borrelia invasion into the host tissues. Plasmin proteolytic activity is presumed to be important during Borrelia transit through tick gut epithelium to the haemocoel ${ }^{100}$. Consequently Borrelia pass through haemocoel to tick salivary glands from where spirochetes are exported to the bloodstream of vertebrate host. Garcia et al. ${ }^{101}$ demonstrated that both OspA and OspB directly bind to vertebrate host complement receptor 3 (CD11b/ CD18) and so induce activation of immune system cells. OspA also activate immune system via binding to Toll-like receptors 1 and 2 (reviwed in Singh and Girschick ${ }^{102}$ ). This may be one of the reasons for the downregulated of OspA/B expression during transmission to vertebrate host which minimizes the immune inflammatory reaction in the early stage of disease. On the other hand, Crowley and Huber ${ }^{103}$ discovered that expression of OspA in vertebrate host is stimulated in an inflammatory environment, particularly after zymosan-induced inflammation. Because the expression of B. burgdorferi s. s. OspA is noted in later stages of mammalian host infection, usually accompanied by arthritis ${ }^{104}$. It is not clear whether increased OspA expression during chronic infection is just the Borrelia response to otherwise induced host inflammatory response to Borrelia or if Borrelia OspA expression is necessary for chronic infection. One explanation for active Borrelia OspA expression during chronic infection is the potential 
protective function of OspA for Borrelia cells. Bunkis \& Barbour ${ }^{105}$ cited OspA as the protease and acid resistant structure on Borrelia surface which shields Borrelia against proteases and low $\mathrm{pH}$ in such "unfriendly" places as the tick gut or inflamed mammalian tissue.

In contrast to an inflammatory environment - antibodies downregulate OspA expression, irrespective of their specificity ${ }^{106,107}$. Thus the regulation of OspA expression resembles positive feedback (inflammation - protection) which must be regulated in Borrelia due to the stage of disease development by as yet not well-understood mechanisms.

\section{Outer surface protein $C$}

Another outer surface protein which is tightly linked to the vertebrate stadium of Borrelia infection is OspC. The $O s p C$ gene is located on cp26 plasmid and encodes a $23 \mathrm{kDa}$ lipoprotein, previously known as $\mathrm{pC}^{108}$. Borreliae lacking this protein are not pathogenic but they can be cultured $^{88}$. The function of this protein was unknown for a long time. Recently the ligand for OspC - tick salivary immunosuppressive protein Salp 15 - was described ${ }^{109}$. It is a soluble component of tick saliva which suppresses the vertebrate host immune response against components of tick saliva during tick engorgement. Salp 15 inhibits proliferation of $\mathrm{CD}^{+} \mathrm{T}$ cells by binding to extracellular domains of the CD4 molecule and inhibits calcium signals needed for activation of transcription factors NF- $\mathrm{kB}$ and NF-AT during $\mathrm{T}$ cell receptor mediated signaling in vivo as well as in vitro ${ }^{110,111}$. In this way Borrelia acquires an immunosuppressive coat of OspC-binded Salp15, which make them undetectable to the vertebrate immune system during the early stage of host colonization. Interestingly, the expression of Salp15 is elevated in infected ticks ${ }^{109}$ as in the case of TROSPA mentioned above. The evolutionary reason for this tick cooperation with its own pathogen is open to question. Newly published data attribute to OspC plasminogen binding activity as was described for OspA above ${ }^{112}$.

However, OspC is not the only protein involved in immune evasion. An essential role is attributed to VlsE, the lipoprotein mentioned in the previous section. The gene for this protein consists of 15 silent $v l s$ cassetes, segments of which are recombined into the $v l s E$ region during mammalian infection ${ }^{113}$. This results in antigenic variability of expressed lipoprotein and thus evasion of specific immune reaction. Recombination of silent fragments into $v l s E$ region occurs only in vivo. Nevertheless signals involved in recombination are unknown. It was found that the number of amino acid changes is significantly higher in immunocompetent $\mathrm{C} 3 \mathrm{H}$ mice than in SCID mice and this suggests an influence of selective pressure ${ }^{114,115}$.

\section{OspEF related proteins and CRASP}

Borrelia is also armed against the activity of complement. And this arm again posses to the host of this bacteria. It has been demonstrated, that one B. burgdorferi s. s. outer surface lipoprotein - OspE, is responsible for Borrelia surface-binding of factor $\mathrm{H}$ in human blood.
Factor $\mathrm{H}$ is a human regulatory protein, inhibiting the activity of complement component $\mathrm{C} 3 \mathrm{~b}$ by means of facilitating its cleavage by factor I and competing with factor B required for formation of $\mathrm{C} 3$ convertase in an alternative pathway of complement activation. Factor $\mathrm{H}$-like protein (FHL), the truncated form of factor $\mathrm{H}$, has a similar function $^{116}$. These mechanisms are used by mammalian cells to protect themselves against non-specific complement activation which could otherwise result in autoimmune damage. Thus Borrelia utilizes the host's own cell surface protective mechanisms. OspE is a member of so-called Erp's (OspEF related proteins), together with proteins coded by genes $O s p F$, erpAB, erpCD, erpG, erpHY, erpIJ, $\operatorname{erp} K, \operatorname{erp} L M, \operatorname{erp} N O$, erpPQ, and $\operatorname{erp} X$. These genes are localized on cp32 plasmids. The exception is the erp $X$ localized on plasmid lp56 (ref. ${ }^{117,}{ }^{118}$ ). The similarities of predicted products of these genes vary between 17-100\% and protein products have diverse ability to bind factor $\mathrm{H}$ in various animal species ${ }^{119}$. Apart from this observation, Kraiczy et al. ${ }^{120,121}$ described a group of proteins capable of binding factor $\mathrm{H}$ and factor $\mathrm{H}$ - like protein (FHL) and designated them CRASPs (Complement regulatoracquiring surface protein). From analysis of differences between CRASP members, the authors explain the variable sensitivity of B. burgdorferi s. S., B. afzeli and B. garinii to the complement observed earlier by Breitner-Ruddock et al. ${ }^{122}$, who divided Lyme disease Borreliae into three groups: complement resistant (B. afzeli), complement sensitive (B. garinii) and complement partially sensitive (B. burgdorferi s. s.). CRASPs appear to be a heterogenic group, because later research showed that some CRASPs members belong to erp family ${ }^{123}$ and at least one, CRASP1 of B. burgdorferi s. s., does not ${ }^{124}$.

\section{Adhesive proteins}

Other B. burgdorferi s. s. group of outer surface proteins included in the pathogenesis of Lyme disease are adhesive molecules which bind vertebrate tissue structures. Decorin binding protein A and B (DbpA, DbpB) bind collagen-associated proteoglycan decorin. ,Borrelia glycosaminoglycans binding protein (Bgp) binding glycosaminoglycans and Fibronectin binding protein (BBK32) binding extracellular protein fibronectin and glycosaminoglycans ${ }^{125,126}$. The mediation of $B$. garinii adhesion to neuronal cell proteoglycans during neuroborreliosis has been recently attributed to OspA, the protein mentioned above $^{127}$. Not fully undersood is role of hemagglutinating lectin B31LEC, but its function in host-pathogen interactions is supposed ${ }^{128,129}$. Borrelia adhesion is discussed in detail by Coburn et al. ${ }^{130}$ and Grubhoffer et al. ${ }^{131}$.

\section{Regulation of expression}

The mechanisms of transcriptional regulation of these proteins are not fully understood but known is the essential role of alternative sigma factors - RpoN $\left(\sigma^{54}\right)$ and $\operatorname{RpoS}\left(\sigma^{38}, \sigma^{\mathrm{s}}\right)$. RpoS expression is activated by RpoN cooperating with response regulatory protein $(\operatorname{Rrp} 2)$ under conditions such as increased temperature or decreased $\mathrm{pH}$. RpoS induces expression of temperature inducible 
genes, like $O s p C, O s p F$ and $D b p A$. In contrast, expression of OspA is dependent on housekeeping factor RpoD $\left(\sigma^{70}\right)$ and is downregulated by the RpoS dependent pathway $^{132-134}$.

\section{CONCLUSIONS}

In spite of considerable research progress on the biology of Borrelia in the most recent years, some features of this bacteria remain obscure. Further, most publications focus only on one species - Borrelia burgdorferi s. s. This may be due to the concentration of Borrelia research groups in the USA where Borrelia burgdorferi $\mathrm{s}$. $\mathrm{s}$. is the only pathogenic species of this group while the situation in Europe is different. Continued research in this field is important not only from the medical point of view but also because it yields valuable outcomes for understanding a number of general biological questions such as plasmid plasticity, antigenic variation and vector-pathogen-host interactions.

\section{ACKNOWLEDGEMENTS}

This work was supported by Palacky University Medical faculty Programme for support of young research workers and Ph. D. students 91110051, by grant of Ministry of Education, Youth and Sport Czech Republic MSM 6198959223 and grant of Ministry of Agriculture NAZV QF 3115.

\section{REFERENCES}

1. Barbour AG, Fish D. The biological and social phenomenon of Lyme disease. Science 1993; 260:1610-1616.

2. Halouzka J, Wilske B, Stunzner D, Sanogo YO, Hubálek Z. Isolation of Borrelia afzelii from overwintering Culex pipiens biotype molestus mosquitoes. Infection 1999; 27:275-7.

3. Žakovská A, Nejedlá P, Holíková A, Dendis M. Positive findings of Borrelia burgdorferi in Culex (Culex) pipiens pipiens larvae in the surrounding of Brno city determined by the PCR method. Ann Agric Environ Med 2002; 9:257-259.

4. Halouzka J, Postic D, Hubálek Z. Isolation of the spirochaete Borrelia afzelii from the mosquito Aedes vexans in the Czech Republic. Med Vet Entomol 1998; 12:103-5.

5. Magnarelli LA, Anderson JF. Ticks and biting insects infected with the etiologic agent of Lyme disease, Borrelia burgdorferi. J Clin Microbiol 1988; 26:1482-6.

6. Balmelli T, Piffaretti J. Association between different clinical manifestations of Lyme disease and different species of Borrelia burgdorferi sensu lato. Res Microbiol 1995; 146:329-40.

7. Asbrink E, Brehmer-Andersson E, Hovmark A. Acrodermatitis chronica atrophicans-a spirochetosis. Clinical and histopathological picture based on 32 patients; course and relationship to erythema chronicum migrans Afzelius. Am J Dermatopathol 1986; 8:209-19.

8. Lunemann JD, Zarmas S, Priem S, Franz J, Zschenderlein R, Aberer E, Klein R, Schouls L, Burmester GR, Krause A. Rapid typing of Borrelia burgdorferi sensu lato species in specimens from patients with different manifestations of Lyme borreliosis. J Clin Microbiol. 2001; 39:1130-3

9. Flach AJ, Lavoie PE. Episcleritis, conjunctivitis, and keratitis as ocular manifestations of Lyme disease. Ophthalmology 1990 ; 97:973-5.
10. Mikkila HO, Seppala IJ, Viljanen MK, Peltomaa MP, Karma A. The expanding clinical spectrum of ocular lyme borreliosis. Ophthalmology 2000; 107:581-7.

11. Zrinscak O, Masnec-Paskvalin S, Corak M, Bacani B, Mandic Z. Paralytic strabismus as a manifestation of lyme borreliosis. Coll Antropol. 2005; 29:137-9.

12. Martens H, Zollner B, Zissel G, Burdon D, Schlaak M, MullerQuernheim J. Anti-Borrelia burgdorferi immunoglobulin seroprevalence in pulmonary sarcoidosis: a negative report. Eur Respir J 1997; 10:1356-8.

13. Ishihara M, Ohno S, Ono H, Isogai E, Kimura K, Isogai H, Aoki K, Ishida T, Suzuki K, Kotake S, Hiraga Y. Seroprevalence of antiBorrelia antibodies among patients with confirmed sarcoidosis in a region of Japan where Lyme borreliosis is endemic. Graefes Arch Clin Exp Ophthalmol 1998; 236:280-4.

14. Treib J, Grauer MT, Haass A, Langenbach J, Holzer G, Woessner R. Chronic fatigue syndrome in patients with Lyme borreliosis. Eur Neurol 2000; 43:107-9.

15. MacDonald AB. Spirochetal cyst forms in neurodegenerative disorders, hiding in plain sight. Med Hypotheses. 2006; 67:819-32.

16. MacDonald AB. Plaques of Alzheimer's disease originate from cysts of Borrelia burgdorferi, the Lyme disease spirochete. Med Hypotheses 2006; 67:592-600.

17. Parker JL, White KK. Lyme borreliosis in cattle and horses: a review of the literature. Cornell Vet 1992; 82:253-74.

18. May C, Carter S, Barnes A, McLean C, Bennet TD, Coutts A, Grant CK. Borrelia burgdorferi infection in cats in the UK. J Small Anim Pract 1994; 35:517 - 520.

19. Skotarczak B. Canine borreliosis-epidemiology and diagnostics. Ann Agric Environ Med 2002; 9:137-40.

20. Johnson, RC, Schmid GP, Hyde FW, Steigerwalt AG, Brenner DJ. Borrelia burgdorferi sp. nov.: etiologic agent of Lyme disease. Int J Syst Bacteriol 1984; 34:496-497.

21. Baranton G, Postic D, Saint Girons I, Boerlin P, Piffaretti JC, Assous M, Grimont PA. Delineation of Borrelia burgdorferi sensu stricto, Borrelia garinii sp. nov., and group VS461 associated with Lyme borreliosis. Int J Syst Bacteriol 1992; 42:378-83

22. Canica MM, Nato F, du Merle L, Mazie JC, Baranton G, Postic D. Monoclonal antibodies for identification of Borrelia afzelii sp. nov. associated with late cutaneous manifestations of Lyme borreliosis. Scand J Infect Dis 1993; 25:441-8.

23. Marconi RT, Liveris D, Schwartz L. Identification of Novel Insertion Elements, Restriction Fragment Length Polymorphism Patterns, and Discontinuous 23S rRNA in Lyme Disease Spirochetes: Phylogenetic Analyses of rRNA Genes and Their Intergenic Spacers in Borrelia japonica sp. nov. and Genomic Group 21038 (Borrelia andersonii sp. nov.) Isolates. J Clin Microbiol 1995; 33:2427 - 2434.

24. Fukunaga M, Hamase A, Okada K, Nakao M. Borrelia tanukii sp. nov. and Borrelia turdae sp. nov. found from ixodid ticks in Japan: rapid species identification by $16 \mathrm{~S}$ rRNA gene-targeted PCR analysis. Microbiol Immunol 1996; 40:877-81.

25. Diza E, Papa A, Vezyri E, Tsounis S, Milonas I, Antoniadis A. Borrelia valaisiana in cerebrospinal fluid. Emerg Infect Dis 2004; 10:1692-3.

26. Wang Q, van Dam AP, Le Fleche A, Postic D, Peter O, Baranton G, de Boer R, Spanjaard L, Dankert J. Genetic and phenotypic analysis of Borrelia valaisiana sp. nov. (Borrelia genomic groups VS116 and M19). Int J Syst Bacteriol 1997; 47:926-32.

27. Collares-Pereira M, Couceiro S, Franca I, Kurtenbach K, Schafer SM, Vitorino L, Goncalves L, Baptista S, Vieira ML, Cunha C. First isolation of Borrelia lusitaniae from a human patient. J Clin Microbiol 2004; 42:1316-8.

28. da Franca I, Santos L, Mesquita T, Collares-Pereira M, Baptista S, Vieira L, Viana I, Vale E, Prates C. Lyme borreliosis in Portugal caused by Borrelia lusitaniae? Clinical report on the first patient with a positive skin isolate. Wien Klin Wochenschr 2005; 117:42932.

29. Le Fleche A, Postic D, Girardet K, Peter O, Baranton G. Characterization of Borrelia lusitaniae sp. nov. by $16 \mathrm{~S}$ ribosomal DNA sequence analysis. Int J Syst Bacteriol 1997; 47:921-5. 
30. Masuzawa T, Takada N, Kudeken M, Fukui T, Yano Y, Ishiguro F, Kawamura Y, Imai Y, Ezaki T. Borrelia sinica sp. nov., a lyme disease-related Borrelia species isolated in China. Int J Syst Evol Microbiol 2001; 51:1817-24.

31. Postic D, Ras NM, Lane RS, Hendson M, Baranton G. Expanded diversity among Californian Borrelia isolates and description of Borrelia bissettii sp. nov. (formerly Borrelia group DN127). J Clin Microbiol 1998; 36:3497-504.

32. Richter D, Postic D, Sertour N, Livey I, Matuschka FR, Baranton G. Delineation of Borrelia burgdorferi sensu lato species by multilocus sequence analysis and confirmation of the delineation of Borrelia spielmanii sp. nov. Int J Syst Evol Microbiol 2006; 56:87381

33. Schwan TG Piesman J. Vector interactions and molecular adaptations of lyme disease and relapsing fever spirochetes associated with transmission by ticks.Emerg Infect Dis. 2002; 8:115-21.

34. Ge Y, Li C, Corum L, Slaughter CA, Charon NW. Structure and expression of the FlaA periplasmic flagellar protein of Borrelia burgdorferi. J Bacteriol 1998; 180:2418-25.

35. Motaleb MA Corum L Bono JL Elias JF Rosa P Samuels DS Charon NW. Borrelia burgdorferi periplasmic flagella have both skeletal and motility functions. Proc Natl Acad Sci U S A. 2000; 97:10899-904.

36. Charon NW Goldstein SF. Genetics of motility and chemotaxis of a fascinating group of bacteria: the spirochetes. Annu Rev Genet. 2002; 36:47-73.

37. Wolgemuth CW Charon NW Goldstein SF Goldstein RE. The Flagellar Cytoskeleton of the Spirochetes. J Mol Microbio. Biotechnol. 2006; 11:221 - 227.

38. Takayama K Rothenberg RJ Barbour AG. Absence of lipopolysaccharide in the Lyme disease spirochete, Borrelia burgdorferi. Infect Immun 1987; 55:2311-3.

39. Fraser CM Casjens S Huang WM Sutton GG Clayton R Lathigra $\mathrm{R}$ White $\mathrm{O}$ et al.. Genomic sequence of a Lyme disease spirochaete, Borrelia burgdorferi. Nature 1997; 390:580-586.

40. Bergstrom S Noppa L Gylge A Ostberg Y. Molecular and Cellular Biology of Borrelia burgdorferi sensu lato. In: J. Gray, O. Kahl, R.S. Lane, G. Stanek (Eds): Lyme borreliosis: Biology, Epidemiology and Control. CAB International; 2002. p. 47 - 90.

41. Hossain H, Wellensiek HJ, Geyer R, Lochnit G. Structural analysis of glycolipids from Borrelia burgdorferi. Biochimie. 2001; 83:68392.

42. Ben-Menachem G, Kubler-Kielb J, Coxon B, Yergey A, Schneerson R. A newly discovered cholesteryl galactoside from Borrelia burgdorferi. Proc Natl Acad Sci U S A. 2003; 100:7913-8.

43. Pozsgay V, Kubler-Kielb J. Synthesis of an experimental glycolipoprotein vaccine against Lyme disease. Carbohydr Res. 2007; 342:621-6.

44. Barbour AG. Isolation and cultivation of Lyme disease spirochetes. Yale J Biol Med 1984; 57:521-525.

45. Callister SM, Case KL, Agger WA, Schell RF, Johnson RC, Ellingson JL. Effects of bovine serum albumin on the ability of Barbour-Stoenner-Kelly medium to detect Borrelia burgdorferi. J Clin Microbiol 1990; 28:363-5.

46. Pollack RJ, Telford SR 3rd, Spielman A. Standardization of medium for culturing Lyme disease spirochetes. J Clin Microbiol 1993; 31: 1251-5.

47. Wang G, Iyer R, Bittker S, Cooper D, Small J, Wormser GP, Schwartz I. Variations in Barbour-Stoenner-Kelly culture medium modulate infectivity and pathogenicity of Borrelia burgdorferi clinical isolates. Infect Immun 2004; 72:6702-6

48. Posey JE, Gherardini FC. Lack of a role for iron in the Lyme disease pathogen. Science. 2000; 288:1651-3.

49. Kurtti TJ, Munderloh UG, Johnson RC, Ahlstrand GG. Colony formation and morphology in Borrelia burgdorferi. J Clin Microbiol 1987; 25:2054-2058.

50. Sung SY, McDowell JV, Carlyon JA, Marconi RT. Mutation and recombination in the upstream homology box-flanked ospE-related genes of the Lyme disease spirochetes result in the development of new antigenic variants during infection. Infect Immun 2000; 68:1319-27.
51. Brorson $\mathrm{O}$, Brorson $\mathrm{SH}$. An in vitro study of the activity of telithromycin against mobile and cystic forms of Borrelia afzelii. Infection 2006; 34:26-8

52. Brorson O, Brorson SH Transformation of cystic forms of Borrelia burgdorferi to normal, mobile spirochetes. Infection 1997; 25:240 $-246$.

53. MacDonald AB. A life cycle for Borrelia spirochetes? Med Hypotheses. 2006; 67: 810-8.

54. Murgia R, Cinco M. Induction of cystic forms by different stress conditions in Borrelia burgdorferi. APMIS 2004; 112:57-62.

55. Murgia R, Piazzetta C, Cinco M. Cystic forms of Borrelia burgdorferi sensu lato: induction, development, and the role of RpoS. Wien Klin Wochenschr 2002; 114:574-9.

56. Baril C, Richaud C, Baranton G, Saint Girons I. Linear chromosome of Borrelia burgdorferi. Res Microbiol 1989; 140:507-516.

57. Ferdows MS, Barbour AG. Megabase-sized linear DNA in the bacterium Borrelia burgdorferi, the Lyme disease agent. Proc Natl Acad Sci USA 1989; 86: 5969-5973.

58. Davidson BE, MacDougall J, Saint Girons I. Physical map of the linear chromosome of the bacterium Borrelia burgdorferi 212, a causative agent of Lyme disease, and localization of rRNA genes. J Bacteriol 1992; 174:3766-3774

59. Casjens S, Huang WM. Linear chromosomal physical and genetic map of Borrelia burgdorferi, the Lyme disease agent. Mol Microbiol 1993; 8:967-980.

60. Ojaimi C, Davidson BE, Saint Girons I, Old IG. Conservation of gene arrangement and an unusual organization of rRNA genes in the linear chromosomes of the Lyme disease spirochaetes Borrelia burgdorferi, B. garinii and B. afzelii. Microbiology 1994; 140: 29312940

61. Casjens S, Delange M, Ley HL, Rosa P, Huang WM. Linear chromosomes of Lyme disease agent spirochetes: genetic diversity and conservation of gene order. J Bacteriol 1995; 177:2769-2780

62. Casjens S. Borrelia genomes in the year 2000. J Mol Microbiol Biotechnol 2000; 2: 401-410.

63. Casjens S, Palmer N, van Vugt R, Huang WM, Stevenson B, Rosa $\mathrm{P}$, Lathigra $\mathrm{R}$ et al. A bacterial genome in flux: the twelve linear and nine circular extrachromosomal DNAs in an infectious isolate of the Lyme disease spirochete Borrelia burgdorferi. Mol Microbiol 2000; 35:490-516.

64. Casjens $\mathrm{S}$. The diverse and dynamic structure of bacterial genomes. Annual Review of Genetics 1998; 32:339-377.

65. Casjens S, Murphy M, DeLange M, Sampson L, van Vugt R, Huang WM. Telomeres of the linear chromosomes of Lyme disease spirochaetes: nucleotide sequence and possible exchange with linear plasmid telomeres. Mol Microbiol 1997; 26:581-96.

66. Casjens S, van Vugt R, Tilly K, Rosa PA, Stevenson B. Homology throughout the multiple 32-kilobase circular plasmids present in Lyme disease spirochetes. J Bacteriol 1997; 179:217-27.

67. Stevenson B, Miller JC. Intra- and interbacterial genetic exchange of Lyme disease spirochete erp genes generates sequence identity amidst diversity. J Mol Evol 2003; 57:309-24.

68. Meinhardt F, Schaffrath R, Larsen M. Microbial linear plasmids. Appl Microbiol Biotechnol 1997; 47:329-36.

69. Rybchin VN, Svarchevsky AN. The plasmid prophage N15: a linear DNA with covalently closed ends. Mol Microbiol 1999; 33:895903.

70. Abs El-Osta YG, Hillier AJ, Davidson BE, Dobos M. Pulsed-field gel electrophoretic analysis of the genome of Lactobacillus gasseri ATCC 33323, and construction of a physical map.Electrophoresis 2002; 23:3321-31.

71. Akins DR, Caimano MJ, Yang X, Cerna F, Norgard MV, Radolf JD. Molecular and evolutionary analysis of Borrelia burgdorferi 297 circular plasmid-encoded lipoproteins with OspE- and OspF-like leader peptides. Infect Immun 1999; 67:1526-32.

72. Stevenson B, Casjens S, van Vugt R, Porcella SF, Tilly K, Bono JL, Rosa P. Characterization of cp 18, a naturally truncated member of the cp32 family of Borrelia burgdorferi plasmids. J Bacteriol 1997; 179:4285-4291.

73. Eggers CH, Samuels DS. Molecular evidence for a new bacteriophage of Borrelia burgdorferi. J Bacteriol 1999; 181:7308-13. 
74. Eggers CH, Kimmel BJ, Bono JL, Elias AF, Rosa P, Samuels DS Transduction by phiBB-1, a bacteriophage of Borrelia burgdorferi. J Bacteriol 2001; 183:4771-8.

75. Glockner G, Schulte-Spechtel U, Schilhabel M, Felder M, Suhne J, Wilske B, Platzer M. Comparative genome analysis: selection pressure on the Borrelia vls cassettes is essential for infectivity. BMC Genomics 2006; 7:211.

76. Labandeira-Rey M, Skare JT. Decreased infectivity in Borrelia burg dorferi strain B31 is associated with loss of linear plasmid 25 or 28-1. Infect Immun 2001; 69:446-455.

77. Labandeira-Rey M, Seshu J, Skare JT. The Absence of Linear Plasmid 25 or 28-1 of Borrelia burgdorferi Dramatically Alters the Kinetics of Experimental Infection via Distinct Mechanisms. Infect Immun 2003; 71:4608-4613.

78. Lawrenz MB, Wooten RM, Norris SJ. Effects of vlsE complementation on the infectivity of Borrelia burgdorferi lacking the linear plasmid 1p28-1. Infect Immun 2004; 72:6577-85.

79. Grimm D, Eggers CH, Caimano MJ, Tilly K, Stewart PE, Elias AF, Radolf JD, Rosa PA. Experimental assessment of the roles of linear plasmids $1 \mathrm{p} 25$ and $1 \mathrm{p} 28-1$ of Borrelia burgdorferi throughout the infectious cycle. Infect Immun 2004; 72:5938-5946.

80. Strother KO, de Silva A. Role of Borrelia burgdorferi linear plasmid 25 in infection of Ixodes scapularis ticks. J Bacteriol 2005; 187:5776-81

81. Purser JE, Norris SJ. Correlation between plasmid content and infectivity in Borrelia burgdorferi. Proc Natl Acad Sci USA 2000; 97:13865-13870.

82. Iyer R, Kalu O, Purser J, Norris S, Stevenson B, Schwartz I. Linear and circular plasmid content in Borrelia burgdorferi clinical isolates. Infect Immun 2003; 71:3699-706.

83. Margolis N, Hogan D, Tilly K, Rosa PA. Plasmid location of Borrelia purine biosynthesis gene homologs. J Bacteriol 1994; 176:6427-6432.

84. Byram R, Stewart PE, Rosa P. The essential nature of the ubiquitous 26-kilobase circular replicon of Borrelia burgdorferi. J Bacteriol 2004; 186:3561-3569

85. Jayaram, M. Split target specificity of ResT: a design for protein delivery, site selectivity and regulation of enzyme activity? Mol Microbiol. 2007; 64:575-9.

86. Stewart PE, Wang X, Bueschel DM, Clifton DR, Grimm D, Tilly K, Carroll JA, Weis JJ, Rosa PA. Delineating the requirement for the Borrelia burgdorferi virulence factor OspC in the mammalian host.Infect Immun 2006; 74:3547-53.

87. Tilly K, Krum JG, Bestor A, Jewett MW, Grimm D, Bueschel D, Byram R. Borrelia burgdorferi OspC protein required exclusively in a crucial early stage of mammalian infection.Infect Immun 2006 74:3554-64.

88. Grimm D, Tilly K, Byram R, Stewart PE, Krum JG, Buesche DM, Schwan TG, Policastro PF, Elias AF, Rosa PA. Outer-surface protein $\mathrm{C}$ of the Lyme disease spirochete: a protein induced in ticks for infection of mammals. Proc Natl Acad Sci U S A 2004; 101:3142-7.

89. Strother KO, Broadwater A, De Silva A. Plasmid requirements for infection of ticks by Borrelia burgdorferi.Vector Borne Zoonotic Dis 2005; 5:237-45.

90. Actis LA, Tolmasky ME, Crosa JH. Bacterial plasmids: replication of extrachromosomal genetic elements encoding resistance to antimicrobial compounds. Front Biosci 1999; 4:D43-62.

91. Schwan TG, Piesman J, Golde WT, Dolan MC, Rosa PA. Induction of an outer surface protein on Borrelia burgdorferi during tick feeding. Proc Natl Acad Sci USA 1995; 92:2909-2913.

92. de Silva AM, Fikrig E. Arthropod- and host-specific gene expression by Borrelia burgdorferi. J Clin. Investig 1997; 99:377-379.

93. Schwan TG, Piesman J. Temporal changes in outer surface proteins $\mathrm{A}$ and $\mathrm{C}$ of the lyme disease-associated spirochete, Borrelia burgdorferi, during the chain of infection in ticks and mice. J Clin Microbiol 2000; 38:382-388.

94. Tokarz R, Anderson JM, Katona LI, Benach JL. Combined effects of blood and temperature shift on Borrelia burgdorferi gene expression as determined by whole genome DNA array. Infect Immun 2004; 72:5419-5432.
95. Barbour AG, Tessier SL, Todd WJ. Lyme disease spirochetes and ixodid tick spirochetes share a common surface antigenic determinant defined by a monoclonal antibody. Infect Immun 1983; 41:795-804.

96. Howe TR, Mayer LW, Barbour AG. A single recombinant plasmid expressing two major outer surface proteins of the Lyme disease spirochete. Science 1985; 227:645-646.

97. Templeton TJ. Borrelia outer membrane surface proteins and transmission through the tick. J Exp Med 2004; 199:603-6.

98. Pal U, Li X, Wang T, Montgomery RR, Ramamoorthi N, Desilva AM, Bao F, et al. TROSPA, an Ixodes scapularis receptor for Borrelia burgdorferi.Cell 2004; 119:457-68.

99. Lahteenmaki K, Kuusela P, Korhonen TK. Bacterial plasminogen activators and receptors.FEMS Microbiol Rev 2001; 25:531-52.

100. Fuchs H, Wallich R, Simon MM, Kamer MD. The outer surface protein A of the spirochete Borrelia burgdorferi is a plasmin(ogen) receptor. Proc Natl Acad Sci U S A 1994; 91:12594-12598.

101. Garcia RC, Murgia R, Cinco M. Complement receptor 3 binds the Borrelia burgdorferi outer surface proteins OspA and OspB in an iC3b-independent manner. Infect Immun. 2005; 73:6138-42.

102. Singh SK, Girschick HJ. 2006. Toll-like receptors in Borrelia burgdorferi-induced inflammation. Clin Microbiol Infect 2006; 12:705-717.

103. Crowley H, Huber BT. Host-adapted Borrelia burgdorferi in mice expresses OspA during inflammation. Infect Immun. 71(7), 400310.

104. Kalish RA, Leong JM, Steere AC. Association of treatment-resistant chronic Lyme arthritis with HLA-DR4 and antibody reactivity to OspA and OspB of Borrelia burgdorferi.Infect Immun 61, 2774-9.

105. Bunkis J, Barbour AG. Access of antibody or trypsin to an integral outer membrane protein (P66) of Borrelia burgdorferi is hindered by Osp lipoproteins. Infect Immun 1999; 67:2874-2883.

106. Dorward DW, Huguenel ED, Davis G, Garon CF. Interactions between extracellular Borrelia burgdorferi proteins and non-Borreliadirected immunoglobulin M antibodies. Infect Immun 1992; 60: 838-44.

107. Hodzic E, Tunev S, Feng S, Freet KJ, Barthold SW. Immunoglobulin-regulated expression of Borrelia burgdorferi outer surface protein A in vivo. Infect Immun 2005; 73:3313-21.

108. Marconi RT, Samuels DS, Garon CF. Transcriptional analyses and mapping of the ospC gene in Lyme disease spirochetes.J Bacteriol 1993; 175:926-32.

109. Ramamoorthi N, Narasimhan S, Pal U, Bao F, Yang XF, Fish D, Anguita J, et al. The Lyme disease agent exploits a tick protein to infect the mammalian host. Nature 2005; 436:573-7.

110. Garg R, Juncadella IJ, Ramamoorthi N, Ashish, Ananthanarayanan SK, Thomas V, Rincon M, et al. Cutting edge: CD4 is the receptor for the tick saliva immunosuppressor, Salp15.J Immunol. 2006; 177:6579-83.

111. Anguita J, Ramamoorthi N, Hovius JW, Das S, Thomas V, Persinski R, Conze D, et al. Salp15, an ixodes scapularis salivary protein, inhibits CD4(+) T cell activation. Immunity 2002; 16:849-59.

112. Lagal V, Portnoi D, Faure G, Postic D, Baranton G. Borrelia burgdorferi sensu stricto invasiveness is correlated with OspCplasminogen affinity. Microbes Infect 2006; 8:645-52.

113. Zhang JR, Hardham JM, Barbour AG, Norris SJ. Antigenic variation in Lyme disease borreliae by promiscuous recombination of VMP-like sequence cassettes. Cell 1997; 89:275-285.

114. Zhang JR, Norris SJ. Kinetics and in vivo induction of genetic variation of vlsE in Borrelia burgdorferi. Infect Immun 1998; 66:3689-3697.

115. Ohnishi J, Schneider B, Messer WB, Piesman J, de Silva AM. Genetic variation at the vlsE locus of Borrelia burgdorferi within ticks and mice over the course of a single transmission cycle. $\mathrm{J}$ Bacteriol 2003; 185:4432-4441.

116. Hellwage J, Meri T, Heikkila T, Alitalo A, Panelius J, Lahdenne $\mathrm{P}$, Seppala IJ, Meri S. The complement regulator factor $\mathrm{H}$ binds to the surface protein OspE of Borrelia burgdorferi. J Biol Chem 2001; 276:8427-35 
117. Stevenson B, Bono JL, Schwan TG, Rosa P. Borrelia burgdorferi erp proteins are immunogenic in mammals infected by tick bite, and their synthesis is inducible in cultured bacteria.Infect Immun 1998; 66:2648-54.

118. Babb K, El-Hage N, Miller JC, Carroll JA, Stevenson B. Distinct regulatory pathways control expression of Borrelia burgdorferi infection-associated OspC and Erp surface proteins. Infect Immun. 2001; 69:4146-53.

119. Stevenson B, El-Hage N, Hines MA, Miller JC, Babb K. Differential binding of host complement inhibitor factor $\mathrm{H}$ by Borrelia burgdorferi Erp surface proteins: a possible mechanism underlying the expansive host range of Lyme disease spirochetes. Infect Immun. 2002; 70:491-7.

120. Kraiczy P, Skerka C, Kirschfink M, Zipfel PF, Brade V. Mechanism of complement resistance of pathogenic Borrelia burgdorferi isolates. Int Immunopharmacol 2001; 1:393-401.

121. Kraiczy P, Skerka C, Kirschfink M, Brade V, Zipfel PF. Immune evasion of Borrelia burgdorferi by acquisition of human complement regulators FHL-1/reconectin and Factor H. Eur J Immunol 2001; 31:1674-84.

122. Breitner-Ruddock S, Wurzner R, Schulze J, Brade V. Heterogeneity in the complement-dependent bacteriolysis within the species of Borrelia burgdorferi. Med Microbiol Immunol 1997; 185:25360.

123. Kraiczy P, Hartmann K, Hellwage J, Skerka C, Kirschfink M, Brade V, Zipfel PF, et al. Immunological characterization of the complement regulator factor H-binding CRASP and Erp proteins of Borrelia burgdorferi. Int J Med Microbiol 2004; 293:152-7.

124. Kraiczy P, Hellwage J, Skerka C, Becker H, Kirschfink M, Simon MM, Brade V, et al. Complement resistance of Borrelia burgdorferi correlates with the expression of BbCRASP-1, a novel linear plasmid-encoded surface protein that interacts with human factor $\mathrm{H}$ and FHL-1 and is unrelated to Erp proteins. J Biol Chem 2004; 279:2421-9.

125. Guo BP, Brown EL, Dorward DW, Rosenberg LC, Hook M. Decorin-binding adhesins from Borrelia burgdorferi.Mol Microbiol. 1998; 30:711-23.
126. Fischer JR, LeBlanc KT, Leong JM. Fibronectin binding protein BBK32 of the Lyme disease spirochete promotes bacterial attachment to glycosaminoglycans. Infect Immun. 2006; 74:435-41.

127. Rupprecht TA, Koedel U, Heimerl C, Fingerle V, Paul R, Wilske B, Pfister HW. Adhesion of Borrelia garinii to neuronal cells is mediated by the interaction of OspA with proteoglycans. J Neuroimmunol 2006; 175:5-11

128. Rudenko N, Golovchenko M, Grubhoffer L. Lectin of Borrelia burgdorferi, a new factor of spirochetal virulence? International Conference on Bacterial and Viral Virulence Factors, Smolenice, Slovakia, September 24-28, 2000, Conference Abstracts, pp. 72-73.

129. Rudenko N, Golovchenko M, Grubhoffer L. Lectin-like sequences in genome of Borrelia burgdorferi. Folia Parasitol 1999;46:8190.

130. Coburn J, Fischer JR, Leong JM. Solving a sticky problem: new genetic approaches to host cell adhesion by the Lyme disease spirochete.Mol Microbiol 2005; 57:1182-95.

131. Grubhoffer L, Golovchenko M, Vancová M, ZacharovováSlavícková K, Rudenko N, Oliver JH Jr. Lyme borreliosis: insights into tick-/host-borrelia relations. Folia Parasitol 2005; 52:27994.

132. Hubner A, Yang X, Nolen DM, Popova TG, Cabello FC, Norgard MV. Expression of Borrelia burgdorferi OspC and DbpA is controlled by a RpoN-RpoS regulatory pathway. Proc Natl Acad Sci U S A 2001; 98:12724-9.

133. Caimano MJ, Eggers CH, Hazlett KR, Radolf JD. RpoS is not central to the general stress response in Borrelia burgdorferi but does control expression of one or more essential virulence determinants. Infect Immun. 2004 Nov;72(11):6433-45.

134. Caimano MJ, Eggers CH, Gonzalez CA, Radolf JD. Alternate sigma factor RpoS is required for the in vivo-specific repression of Borrelia burgdorferi plasmid lp54-borne ospA and lp6.6 genes. J Bacteriol 2005; 187:7845-52. 